CHANGES IN THE DISTRIBUTION

OF WAGES, 1940-1950: THE

PUBLIC VS. THE PRIVATE SECTOR

Robert A. Margo

T. Aldrich Finegan

Working Paper 5389

NATIONAL BUREAU OF ECONOMIC RESEARCH

1050 Massachusetts Avenue

Cambridge, MA 02138

December 1995

We are grateful to Larry Katz for suggesting the variance decomposition approach used in the paper, to participants in the NBER Summer Institute for helpful comments, and to Simon Wu for research assistance. This paper is part of NBER's research program in Development of the American Economy. Any opinions expressed are those of the authors and not those of the National Bureau of Economic Research.

() 1995 by Robert A. Margo and T. Aldrich Finegan. All rights reserved. Short sections of text, not to exceed two paragraphs, may be quoted without explicit permission provided that full credit, including 0 notice, is given to the source. 


\title{
CHANGES IN THE DISTRIBUTION \\ OF WAGES, 1940-1950: THE \\ PUBLIC VS. THE PRIVATE SECTOR
}

\begin{abstract}
Between 1940 and 1950 wage differentials within and between labor market groups narrowed significantly - the so-called "Great Compression". This paper disaggregates the Great Compression into its public and private components. Wage compression in the public sector, along with a decline in the pay premia received by public sector workers, explains about $\mathbf{4 0}$ percent of aggregate wage compression in the 1940s. The experience of the 1940s stands in stark contrast with that of the past two decades, in which a rigid public sector wage structure has dampened increases in aggregate wage inequality.
\end{abstract}

Robert A. Margo

Room 412 Calhoun

Department of Economics

Vanderbilt University

Nashville, TN 37235

and NBER
T. Aldrich Finegan

Department of Economics

Vanderbilt University

Nashville, TN 37235 
1. 0 Introduction

The $1940 \mathrm{~s}$ were yearg of remarkable narrowing in the distribution of wages - the so-called "Great compression" (Goldin and Margo, 1992). Wage differentials declined both between and within groupg between 1940 and 1950 . In 1940 , for example, the ratio of weekly wages of male college and high school graduates with 11 to 15 years of work experience was 1.78 , but by 1950, the ratio had fallen to 1.46 (Goldin and Margo 1992 , p. 5). Wage differentials within groups also fell, as indicated by the residual variance from log wage regressions controlling for worker characteristics (Goldin and Margo, 1992, p. 12).

The distributional experience of the $1940 \mathrm{~s}$ is of interest to labor economists today because it provides an historical benchmark to evaluate current levels of wage inequality. previous research suggests that, by the late 1980 , aggregate wage inequality had reached levels not seen in the U.S. since 1940 (Goldin and Margo, 1992, p. 2; Katz and Murphy, 1992). Government employment, however, is a larger share of aggregate employment today than in 1940.1 Recent research suggests that the distribution of government wages is much more compressed today than the distribution of private sector wages. In addition, wage inequality in the public sector has remained essentially unchanged since the early 1970 . Consequently, the rise in wage inequality over the past quarter century has been almost exclusively a private sector phenomenon lkatz and krueger 
1991). It is unclear, however, whether government wages played a similar role in the 1940s, because previous research on the Great Compresaion examined changes in aggregate wage distributions, not at the sectoral level (Goldin and Margo 1992).

The purpose of this paper is to decompose the Great Compression into its public and private components. The analysis is based on extracts of public and private sector employees drawn from the public use microdata samples (PUMS) of the 1940 and 1950 federal censuses, in conjunction with data from various BLs reports of the era. Because census data identify sector of employment as well as worker characteristics, we can examine differences in wage distributions between and within the public and private sectors, as well as the sources of change over time, insofar as these are captured by worker characteristics and their market valuations.

2. The context for Distributional change: public and private Wages in the $1940 \mathrm{~s}$

Government wage-setting policies in the $1970 \mathrm{~s}$ and $1980 \mathrm{~s}$ have yielded a public sector wage distribution that is substantially compressed relative to its private sector counterpart, and which has exhibited little overall change since the early $1970 s$, especially in the federal government (Katz and Krueger l991; Johnson and Libecap 1994). As a result, these policies have gerved to dampen the overall rise in aggregate wage inequality 
that has occurred in the past two decades. Given the recent increase in private sector wage inequality relative to the public sector, high-wage government workers now appear to be underpaid relative to their (observationally equivalent) private sector counterparts, while the reverse is true for low-wage workers (Katz and Krueger, 1991, p. 151).2 In turn, these pay gaps for government workers have reduced quit rates among less-skilled employees and, in some cases, led to queues for government jobs while simultaneously exacerbating retention problems for highlyskilled workers (Krueger, 1988; Katz and Krueger, 1991).

There are several reasong to believe, however, that government wage-setting policies may have reinforced, not dampened, aggregate wage compression between 1940 and 1950. First, during the first half of the twentieth century, governments at all levels in the U.S. "attempted to follow some approximation of the prevailing rate in fixing the pay of their employees" (spero, 1948, p. 424) - - that is, pay in the public sector was set relative to pay in the private sector. ${ }^{3}$ The prevailing rate policy was easiest to implement in the case of public sector workers whose jobs had obvious counterparts in the private sector - typically, less educated workers in blue collar occupations (spero, 1949, p. 441).4 As previously noted, the returns to schooling fell between 1940 and 1950 ; consistent with this decline, blue collar wages rose relative to white collar wages over the decade (Goldin and Margo, 1992, p. 9). To the extent that prevailing rate policies caused government wage 
levels to be tied effectively to private sector wage levels, particularly among less-educated workers, public sector wages should have been compressed alongside private sector wages between 1940 and 1950 .

Second, the average pay premia for government work on the eve of world war Two were eroded over the course of the 1940 . According to National Income and Product Accounts (NIPA) estimates, the federal-to-private (nonfarm) ratio of average annual earnings was 1.40 in 1939; the corresponding figure for state and local (non-education) government workers was 1.12 . By 1949. the federal-private earnings ratio had declined to 1.18 , while the ratio for state and local workers had fallen to 0.95 .5 Even if there had been no change in the distribution of wages within sectors, declines in wage gaps between sectors would have reduced overall wage inequality. The NIPA estimates are national aggregates, however, and it is unclear how much of the decline in the average pay premia was due to changes in the relative compensation of government employees versus changes in the characteristics of workers (see section 3.0 ).

Third, there is direct evidence of wage compression in the $1940 s$ for one gub-group of government workers, so-called "classified" federal employees - that is, the federal civil service. 6 The pay of classified employees was set (and altered) by periodic congressional legislation. Throughout its history the Bureau of Labor statistics has conducted "wage chronologies" that document changes in wage distributions in various industries 
and occupations; these findings have appeared in occasional issues of the Monthly Labor Review. Federal classified employees were one such group; by combing through the MLR, it is possible to reconstruct the qualitative and quantitative dimensions of changes in their pay.

Table 1 lists every piece of federal legislation affecting the pay of classified federal employees over the period 1930 to 1949. We include legislation from the $1930 s$ to provide a contrast with the legislation of the l940s, as well as to shed light on the origins of the federal-private pay gap in 1940 (see below). The titles and dates of each piece of legislation and a brief summary of its major provisions are shown, along with our interpretation how it changed the structure of classified pay.

With the exception of the Brookhart Act of 1930 , federal pay legislation in the $1930 \mathrm{~s}$ had a neutral effect on the wage structure among classified employees. In 1932 and again in 1933 , federal pay was reduced across the board, but by uniform percentage amounts, leaving the (relative) wage structure unchanged. Over the next two years the pay cuts were restored so that, by April of 1935, classified pay had regained its 1932 level, prior to the wage cuts. By the same time, nominal earnings of non-farm workers were lower in 1935 than in 1929 - indeed, they were still lower in 1939 (Lebergott, 1964, p. 524). Thus, the wage chronology suggests that federal workers may have been overpaid on the eve of world war Two because of congressional willingness to restore cuts in nominal wages long before tighter 
labor markets in the early 1940 s forced private sector employers to follow suit.

The impact of the l940s legislation on the classified pay structure contrasts vividly with the $1930 \mathrm{~s}$ legislation. The earliest piece of $1940 \mathrm{~s}$ legislation, the Mead-Ramspeck Act of 1941, continued the $1930 \mathrm{~s}$ tradition of a neutral effect. However, both the custodial Pay Act of 1942 and the Federal Employees Act of 1945 clearly compressed clasified pay, by raising salaries at the low end of the federal pay scale by a larger percentage amount than those at the upper end. The same effects are visible in the Federal Employees Act of 1946 and in the Postal Rate Revision and Federal Employees Act of 1948, which authorized a flat $\$ 330$ increase in all salaries, again unambiguously compressing pay differentials in relative terms.

The final piece of $1940 s$ legislation was the classification Act of 1949. The act compressed classified pay by establishing a national pay plan for all civil service employees, thereby reducing geographic wage differentials in the federal government (Johnson and Libecap, 1994). However, the act also authorized the creation of several new, highly-paid, "general-service" (GS) levels, which potentially expanded the range of federal pay at the top end. In terms of data analyzed in this paper (see section 3.0$)$, it is unlikely that the classification Act had much impact, because the act did not become effective until the fourth quarter of 1949.7

In addition to describing the various pieces of legislation, 
the BLs wage chronologies reported official wage schedules for classified employees that give the salary ranges for the various GS levels. Examination of the chronologies indicates clearly that the legislation produced wage compression by altering the structure of federal pay - that is, by narrowing the gap in wages between workers at different GS levels. As an example of this point, figure 1 graphs the ratio of the midpoints of the legislated salary ranges of GS-8 "clerical-administrative" workers - a white collar group - and Gs-4 "craft-custodial" workers - a blue collar group for 1930-50. Consistent with our analysis of the pay legislation, the ratios remain constant during the 1930s, but plummet sharply in the $1940 \mathrm{~s}$.

In compressing the classified pay structure, the $1940 \mathrm{~s}$ legislation was effective in maintaining wage parity with the private sector at the GS-4 level (and below). Figure 2 charts the federal-private wage ratio for Gs-4 classified employees relative to the average annual earnings of full-time 12,000 annual hours) manufacturing production workers between 1930 and 1949. This ratio peaked in the early $1930 \mathrm{~s}$, when nominal wages fell sharply in the private sector, particularly for less-skilled workers (Goldin and Margo 1992) while, as previously noted, federal wage cuts left the structure of classified pay unchanged. By the early $1940 \mathrm{~s}$, lagging federal wages had created a pay gap in favor of production workers. The wartime legislation, however, restored the wage ratio to near parity by 1949 . At the same time, however, the NIPA series demonstrates that the average pay 
premia for federal workers declined sharply, indicating that highly paid federal workers had fallen behind their private sector counterparts.8

In sum, various factors suggest that government wages may have compressed during the 1940s, and that government wage premia diminished. In order to quantify the impact of such changes on aggregate wage inequality, census microdata are necessary.

3. Data Analysis

We elaborate on the points made in section 2 through an analysis of extracts from the 1940 and 1950 one percent public use samples of the federal cenguses of population (U.S. Bureau of the Census 1984a, 1984b). We create two extracts from each pums - a private sector sample, and a public sector sample. In both samples we restrict our attention to adult males, ages 18 to 64 who (1) were nonfarm wage and salary workerg who worked at least 40 weeks in the year prior to the census (2) were not on work relief (for example, the works Projects Administration) at the time of the census; or, if unemployed at the time of the census, had not been on work relief in 1939 and (3) earned at least onehalf of the federal minimum wage on a weekly, full-time (40 hours) basis in the year prior to the census. 9 sector (public or private) is identified from information on the industry and "class" of worker. 10 As far as possible, all members of the armed forces are excluded. 11 
It is important to note that census earnings data refer to the year prior to the census, but the question on clags of worker (and industry) pertaing to the census week (March 24-30, 1940 ). A person might have been employed in the auto industry in 1939 but in the steel industry in 1940. Because the sectors we are examining are very broad, however, any such transitions are apt to be quantitatively unimportant. Nonetheless, it is possible that some workers classified in the private sector lon the basis of, for example, class of worker) worked in the public sector in 1939, or vice versa. Unfortunately, no information is available in the census on pensions, or other fringe benefits.

The analysis is based primarily on variance decompositions of the log of weekly earnings, such as the following

$$
\sigma^{2}(\ln w)=B_{p} \sigma_{p}^{2}+B_{g} \sigma^{2} g+B_{p} B_{g}\left[\ln \left(\mu_{p} / \mu_{g}\right)\right]^{2}
$$

where $p=$ private sector, $g=$ government, $B_{i}=$ share of workers in sector $i\left(B_{p}+B_{g}=1\right)$, and $\ln \left(\mu_{p} / \mu_{g}\right)$ is the log of the ratio of mean incomes in the two sectors.12

Equation (1) identifies the various mechanisms by which the public sector wage distribution might affect the overall wage inequality. First, $\sigma^{2}$ i might differ between the public and private sectors; if it does, changes in $B_{i}$ will alter the overall variance. Second, even if the B's are fixed over time, changes in $\sigma^{2}$ i might occur. Finally, the overall variance depends on ln $\left(\mu_{\mathrm{p}} / \mu_{\mathrm{g}}\right)$, the log gap in mean wages - if this gap falls, overall 
inequality will decrease.

Panel A of Table 2 shows the initial variance decompositions for 1940 and 1950 . Unlike today, government employment was not a force for overall wage equality in 1940. The variance of government wages was slightly higher than the variance of private sector wages, and government pay, on average, was higher. Because government wages did not compress the aggregate distribution in 1940, but have done so more recently, private sector wage inequality in the mid-1980s was higher than on the eve of world war Two. The apparently similarity in aggregate wage inequality between $1940 \mathrm{~s}$ and the mid-1980s is a consequence of government wage compression and secular growth in government employment.

The Great compression is visible in the decline in $\sigma^{2}$ ' from 0.285 in 1940 to 0.256 in 1950. However, it is also apparent that the decline in the overall variance was greater than in the decline in the private sector variance. The overall variance declined more than the private sector variance because the variance of government wages fell even more than the private sector variance, and because government wage premia declined.

The quantitative impact of these changes is evaluated in Panel B, which allocates the decline in the overall variance to its various components. Given that the overwhelming share of the labor force in 1940 was in the private sector, it is not surprising that the decline in $\sigma^{2}$ p was the most important component. However, if the variance of government wages and the 
public-private wage gap had remained unchanged over the $1940 \mathrm{~s}$, it is also clear that the decline in the overall variance would have been much smaller. Fully one-third of that decline can be attributed to a smaller variance of wages within the public sector.

While Table 2 establighes that changes in the mean and variance of government wages played a quantitatively significant role in producing the Great compression. It is unclear from Table 2, however, whether these changes occurred throughout the different levels of government, or whether they were concentrated, for example, at the federal level (recallour discussion of classified payl. Accordingly, panel A of Table 3 presents a variance decomposition of government wages. The distribution of government wages compressed in both the federal and state and local sectors between 1940 and 1950 , although the compresion was greater (in percentage terms) at the federal level. Relative growth in federal employment was also a factor, because federal wages were more compressed than state and local wages in 1940.13 Finally, both the size of the public-private wage gap, and its associated decline over the $1940 s$, were greater in the federal than in state and local government. The computations in panel $B$ of Table 3 are analogous to those in panel B of Table 2 ; they show that the bulk of the decline in the variance of government wages can be attributed to declines in the variances within the two sectors (federal and state-local).

Consistent with the national income data, Tables 2 and 3 
demonstrate that there were substantial pay gaps in favor of the government in 1940, but that these gaps eroded over the course of the Great compression. A decline in the pay gap could have occurred because of a shift in the composition of worker characteristics in either the public or private sectors, or in the extent to which worker characteristics were rewarded.

To investigate the sources of the pay gap, we employ a standard Blinder (1973) decomposition. For example, in the case of the federal-private pay gap,

$$
\ln w_{p}-\ln w_{f}=\left(x_{p}-x_{f}\right) B_{p}+x_{f}\left(B_{p}-B_{f}\right)
$$

where all variables are measured at their sample means, and the B's are regresion coefficients. Included in the $x$ 's are schooling, labor market experience, race, foreign birth, marital status, census region, and urban-rural status. The regression coefficients are reported in Appendix Table 1 .

Panel A of Table 4 shows the results of the decomposition. Approximately half of the federal-private pay gap in 1940 can be attributed to differences in worker characteristics between sectors. When the effect of these differences was removed, however, federal workers werestill overpaid, by approximately 16 percent $[=\exp (0.154)-1]$. As suggested by the discussion in section 2, an unexplained pay advantage for federal workers in 1940 is consistent with the restoration of Depression-era pay cuts in the mid-1930s. Nearly all of the much smaller 
state/local-private pay gap in 1940 was attributable to differences in worker characteristics; state/local workers were better educated, on average, and had more work experience than private sector workers (see Appendix Table 1 ).

As noted earlier, government workers experienced a marked reduction in the average pay gap over the course of the 1940s. In the case of federal workers, the pay gap shrank (in log terms) by 0.219; the decomposition for 1950 shows that the majority of this decline (0.143 in logs) can be explained by a decline in the overpayment of federal workers. Indeed, by 1950 , it appears that, on average, otherwise identical workers received the same pay in the federal government and in the private sector.14 In the state and local sector, the average pay gap was negative in 1950 (about 5 percent); for observationally equivalent workers, it was about twice as large (0.113 in log terms). Thus, state and local workers began the decade in wage parity (holding worker characteristics constant) but, by 1950, were underpaid relative to their private sector counterparts.

The wage regressions also reveal how much of the decline in within-sector wage inequality can be attributed to changes in the variance in worker characteristics and their market valuations (XB) versus a decline in residual wage inequality ( $\epsilon$ ). According to panel B of Table 3, about three quarters of the decline in private sector wage inequality can be attributed to compression in the predicted component of wages (Xß) as opposed to the unobserved component $(\epsilon)$. As Goldin and Margo (1992) point out, 
much of the decline in the predicted component can be attributed to a reduction in the returns to educational attainment. In the case of government workers, however, a larger fraction of wage compression can be explained by a reduction in the variance of the residual wage distribution, suggesting that government wage compression in the 1940 s acted more to reduce within-group inequality than between-group inequality.

Finally, Table 5 provides some evidence on the extent to which prevailing rate policies might have been the primary conduit for government wage compression. After first dividing up the sectoral samples into two groups - - workers with 12 years or less of schooling, and workers with more than 12 years of schooling --we re-estimated the log wage regressions, including the same variables as before (see Appendix Table 1 ) as well as a full set of state dummy variables. We then estimated labor-force weighted state-level regressions of the coefficients of the state dummies from the government regressions on the coefficients of the private-sector regressions. If our argument in section 2 is correct, we expect to see a positive correlation between the public and private state dummies, one that is larger for lesseducated workers than better-educated workers, and possibly larger as well as the state/local than at the federal level (spero, 1949 ).

In 1940, there was a significant positive correlation ( $B=$ 0.87 , insignificantly different from onel between private sector and state/local government wages, among workers with 12 years or 
less of schooling. Among workers with more than 12 years of schooling, the correlation was also positive, but the magnitude of the coefficient was much smaller (0.39). There also was a positive correlation between federal and private wages, for workers with less than 12 years of schooling, but again the coefficient was small in size. Among better educated workers, state level variation in private sector and federal wages were essentially unrelated in 1940.

In 1950, there was again a significant positive relationship between state/local and private wages among workers with less than 12 years of schooling, but a much less tight correlation among workers with more than 12 years of schooling. State level variation in private sector and federal wages were also positively related among workers with 12 years or less of schooling but, as in 1940, not among better educated workers.

The same general patterns held among federal workers except, as in 1940, the correlation of the state dummies was lower than in the state and local regressions. 15

\section{0 Conclusion}

Since 1940 the two most important episodes in American inequality history are the "Great compression" of the 1940 s and the rise in income inequality during the past two decades. The recent rise in inequality has been almost exclusively a private sector affair; government wages are more compressed than private 
sector wages, and the distribution of government wages has changed little since 1970. The experience of the $1940 \mathrm{~s}$ was exactly the opposite. In the 1940 g government wages compressed along with private sector wages, and relatively large government wage premia in 1940 evaporated over the decade. Although aggregate wage inequality in the mid-1980s was approximately the same as in 1940, it would appear that private sector wage inequality is higher today than on the eve of world war Two.

It is tempting to infer from the results of this paper that various institutional factors, such as the advent of public sector collective bargaining, are responsible for making public sector wage distributions more "rigid" today than at mid-century. In order to test this inference, however, we would need another Great compression, since the institutional factors that have kept government wages compressed in the face of rising private sector wage inequality might not resist further wage compression in the public sector if private sector wage inequality fell. At the very least, however, our results suggest that, in the not-sodistant past, government wage-setting policies were flexible enough to respond to changes in private sector wage inequality. 
Notes

1. In 1985, the year in which aggregate wage inequality approximately equalled the level prevailing in 1940 lsee Goldin and Margo, 1992, p. 2), government employment compriged 16.8 percent of total non-agricultural employees, compared with 12.9 percent in 1940 (computed from Council of Economic Advisors, 1988, pp. 296-297; and Lebergott, 1964, pp. 514-515).

2. There is a substantial labor economics literature on publicprivate wage differences during the post-world War Two period; in addition to Katz and Krueger (1991), important recent studies include smith (1977), Moulton (1990), and Venti (1987).

3. Although many public sector workers belonged to labor organizations ca. 1940, formal collective bargaining lover wages and other working conditions) is a relatively recent phenomenon, dating from 1962 in the federal government, and from 1959 in state and local government; gee Ehrenberg and smith (1994, p. 502). It is frequently argued that public sector unions have promoted a rigid public sector wage structure, although evidence is mixed (see Katz and Krueger, 1991, p. 164). However, even if all government workers had been covered by collective bargaining agreements ca. 1940, it is unclear that the government wage structure would have remained unchanged in the face of declining wage inequality in the private sector, because public land privatel sector unions have long favored wage compression ( Johnson and Libecap, 1995; Katz and Krueger, 1991 ). "Comparability" legislation, which legally requires that federal 
pay be set in reference to annual surveys of private sector workers, has been in place since 1962, but the fact that federal wages have remained compressed in the face of rising private sector wage inequality raises serious questions about the effectiveness of the legislation; see Krueger (1988, p. 567) and Katz and Krueger (1991).

4. At the federal level, workers covered by the Federal wage system have long had their wages set in accordance with recommendations by local wage boards, which pay prevailing rates in specific geographic areas; see Johnson and Libecap (1994, p. $99)$.

5. The estimated earnings ratios in the text were computed from sectoral data on annual earnings and employment in Lebergott (1964, pp. 514, 517, 524,526). It is important to note the Lebergott data included female employees, while our analysis of census data is restricted to males (see section 3.0 ).

6. Johnson and Libecap (1994, p. 111) present estimates of the Gini coefficient of federal pay in 1928 and in 1949 that suggest only a slight decline in wage dispersion (about 11 percent = 1 $0.185 / 0.208$ ) prior to 1950. The source of the 1928 gini is Feldman (1931, Appendix D, p. 265). Feldman's wage sample refers to "field service" federal employees (which excludes federal workers in the District of Columbia), postal workers, and blue workers covered by Federal wage system. The source of the 1949 gini is Office of Personnel Management (1989); the OPM sample covers all federal workers. Thus the 1928 and 1949 figures are 
not comparable.

7. Census earnings data from the 1950 pums pertain to the calendar year 1949 (see section 3.0); thus, at best, the Classification Act could have affected about a quarter's worth of annual earnings.

8. In the sample analyzed in this paper, the federal-private wage gap (in logs) at the 90 h percentile of the wage distribution was 0.444 in 1940 , but only 0.019 in 1950.

9. We exclude persong on New Deal work relief programs becauge there is no clear consensus in the literature whether such persong were "employed" (presumably, in the public sector; see Darby 1976) or "unemployed" (Lebergott 1964). If persons on work relief are counted as public sector employees in 1940, their inclusion markedly increases the dispersion in public sector wages, because relief pay was set on the basis of the so-called "security wage" doctrine, which (in conjunction with lower-thanaverage weekly hours) resulted in relatively low wages; see spero (1949. p. 424-425). Given the scope of work relief in the late $1930 \mathrm{~s}$ and the fact that relief wages were not set on a prevailing rate basis, it seems more appropriate to exclude persons on work relief. Screening on the bagis of work relief status at the time of census eliminates the majority of persons who were on work relief in 1939, because most persons on relief had been so for some time and, prior to their spell on work relief were unemployed; see Margo (1988). It is also possible to exclude persons unemployed at the time of census who had been on work 
relief in 2939 because of a quirk in the 1940 census, which allows the identification of such persons based on an overlap in their reported weeks worked and weeks unemployed; see Fineyan and Margo (1994) for a description of the algorithm used to identify such persong. Despite these screens, it is possible that some persons who were on work relief in 1939 are still included in the state and local sample (see footnote 12).

10. The "class" of worker distinguishes public from private sector employees, but not federal from state and local. We identify "federal" workers with all persons in the sample reporting one of the three federal industry codes in the 1940 pums (postal service, national defense, or federal government, n.e.c., that is, "not elsewhere classified"). state and local government workers are defined to be all persons reporting to be employed by government (as given by the code for class of worker) but reporting a different indugtry code than the federal codes. The industry code for gtate and local government in the 1940 census refers to state and local workers, n.e.c. (industry \#131). which is a much narrower definition of gtate and local employment. The substantive results of the paper regarding government wage compresion in the 1940s, however, are not affected if the state and local sample is defined on the n.e.c. basis, rather than the more general basis described above lsee footnote 12 ). 
11. It is appropriate to exclude members of the armed forces because their (money) wages were very low by private sector standards, and because they received substantial income in kind. In 1950, it is possible to exclude members of the armed forces because they are so identified. In 1940 , members of the armed forces are excluded to the extent that their reported occupation fell into the category "soldier, sailor, etc.". It is possible, therefore, that some non-commissioned officers are included in the 1940 sample. However, the substantive findings of this paper would not change if all persons giving "national defense" as their industry of employment in 1940 (this would include noncommissioned officers) are excluded. It is important to note that the sample definitions in this paper are more restrictive than in Goldin and Margo (1992) in various ways (for example, Goldin and Margo did not exclude persons on work relief), so that direct comparisons of magnitudes (for example, log wage variances in 1940) with those reported by Goldin and Margo would be inappropriate. 12. See Benedict and shaw (1995) for a recent application of variance decompositions to earnings inequality within and between the union and non-union sectors, focussing on the effect of pensions.

13. Although we have taken considerable care to eliminate persons on work relief, it is still possible that some persons on work relief in 1939 are included in the sample. Assuming the instructions to census enumerators were followed (the relevant instructions are par. 567 and 569), such persons would 
necessarily be coded as state and local government employees. For this reason, the decline in the variance of state and local wages between 1940 and 1950 may be larger than if we were able to exclude all persons on work relief. However, if we restrict our attention to a narrow subset of state and local government workers - those reporting their industry of employment as "state and local government, n.e.c." (if the census instructions were followed, persons on work relief would not have been classified in this industry) - the log variance of government wages (federal plus state/local n.e.c.) is 0.239 in 1940 and 0.144 in 1950. Moreover, in 1950, there is no issue of including or excluding persons on work relief, yet the government wage distribution using the n.e.c. definition for state employees is about 23 percent more compressed $(=1-0.144 / 0.186)$ than if the broader definition (see Table 2) is used - - essentially the same ratio $(22$ percent $=1-0.239 / 0.300)$ as existed in 1940. This suggests that results reported in Table 2 - government wages were no less dispersed, and may have been more dispersed, than private sector wages in $1940 \ldots$ is not an artifact of our sample design.

14. Because wages were compressed in the federal government compared with the private sector, however, low-wage federal workers were overpaid relative to their private sector counterparts, while the reverse was true among high-wage workers; a similar pattern is observed today (see Katz and Krueger 1991 ). 
15. The fact that the coefficient in the 1940 federal regregsion is not noticeably smaller than in 1950 supporta our claim that the effectg of the Classification Act of 1949 on earnings data from the 1950 puMs must be minimal, because the act created a national pay plan for federal clagsified employeeg (thereby reducing the extent to which federal wages could have varied with local conditionsl. 
Benedict, Mary Ellen and Kathryn Shaw. 1995. "The Impact of Pension Benefits on the Digtribution of Earned Income." Industrial and Labor Relations Review 48 (July): 740-757.

Blinder, Alan. 1973. "Wage Discrimination: Reduced Form and structural Estimates." Journal of Human Resources 8 (Fall): $436-455$.

Council of Economic Advisors. 1988. Economic Report of the President. Washington, DC: USGPO.

Darby, Michael. 1976. "Three-and-a-Half Million U.S. Employees Have Been Mislaid: Or, An Explanation of Unemployment, 1934 1941." Journal of Political Economy 84 (February): $1-16$.

Ehrenberg, Ronald G. and Robert S. Smith. 1994. Modern Labor Economics: Theory and Public Policy. New York: HarperCollins.

Feldman, Harmann. 1931. A Perfonnel program for the Federal Civil Service. 71 st. Cong. 3d. sess. H. Doc. 773. Washington, DC: USGPO .

Finegan, T. Aldrich and Robert A. Margo. l994. "Work Relief and the Labor Force Participation of Married women in 1940." Journal of Economic History (March 1994): 64-84.

Goldin, Claudia and Robert A. Margo. 1992. "The Great Compression: The Wage structure in the United states at MidCentury," Quarterly Journal of Economics 107 (February): 134. 
Johnson, Ronald N. and Gary D. Libecap. 1994. The Federal Civil Service and the problem of Bureaucracy: The Economics and Politics of Institutional Change. Chicago: University of Chicago press.

Katz, Lawrence F. and Alan B. Krueger. 1991. "Changes in the structure of wages in the public and private sectors," Research in Labor Economics 12: $137-172$.

Katz, Lawrence F. and Kevin M. Murphy. 1992. "Changes in Relative Wages, 1963-1987: Supply and Demand Factors," Quarterly Journal of Economics 107 (February): $35-78$.

Krueger, Alan. 1988. "The Determinants of Queues for Federal Jobs." Industrial and Labor Relations Review 41 (July): 567 581.

Lebergott, Stanley. 1964. Manpower in Economic Growth: The American Record Since 1800. New York: McGraw-Hill.

Margo, Robert. 1988. "Interwar Unemployment in the United states: Evidence from the 1940 Census Sample." In B. Eichengreen and T. Hatton, eds., Interwar Unemployment in International Perspective. pp. 325-352. London: Kluwer Academic Publishers.

Monthly Labor Review, various issues.

Moultron, Brent R. 1990. "A Re-examination of the Federal-Private Wage Differential in the United States," Journal of Labor Economics 8 (April): $270-293$.

Smith, sharon. 1977. Equal Pay in the public sector: Fact or Fantasy? Princeton, NJ: Princeton University Press. 
Spero, sterling D. 1949. Government as Employer. New York: Remsen Press.

U.S. Bureau of the Cengus. 1984a. Census of Population, 1940: Public Use Microdata Sample. Washington, DC: U.S. Department of Commerce.

U.S. Bureau of the Census. 1984b. Censug of population, 1950: Public Use Microdata Sample. Washington, DC: U.S. Department of Commerce.

U.S. Office of Personnel Management. 1989 . Pay structure of the Federal Civil Service. Washington, DC: USGPO.

Venti, Steven F. 1987. "Wages in the Federal and private sectors," in D. Wise, ed. Public sector Payrollg. Chicago: University of Chicago Press. 
Table 1

Wage Chronology: Classified Federal Employees, $1930-1949$

Name (Effective Date) Provisions

Brookhart Act

$(7 / 30 / 30)$

Economy Act

$(7 / 1 / 32)$

Economy Act,

Executive orders

$6035,6188,6533$

$(4 / 1 / 33)$

Independent offices Appropriation Act $(7 / 1 / 34)$

Independent offices Appropriation Act (4/1/35)

Joint Resolution No. 3, 74 th Cong. ist sess.

$(2 / 1 / 35)$

Mead-Ramspeck Act $(7 / 1 / 41)$

Custodial Pay Act $(8-1-42)$

Federal Employees Pay Act of 1945 $(7 / 1 / 45)$

Federal Employees Pay Act of 1946 $(7 / 1 / 46)$

Pogtal Rate Revision and Federal Employees Act of 1948

$(7 / 3 / 48)$

in salaries

in salaries percent cut percent cut 1932 levels
Impact on classified wage structure

Increases of $\$ 200$ in

maximum to $\$ 5,200$

Compress

8. 5 percent decrease

No Change

15 percent decrease

No Change

salary restored to 10

No Change

salary restored to 5

No Change

salary restored to

No Change

Within-grade salary

increases for performance

No Change
Salaries of blue collar and low white collar increased by $\$ 60-200$

Salaries increased by 20

Compress percent for firat $\$ 1,200$; 10 percent for next $\$ 3,400$; 5 percent on remainder up to $\$ 10,000$

Increases of 14 percent or $\$ 250$ per year, whichever greater, up to $\$ 10,000$

$\$ 330$ increase in all

Compress

Compress

Compress salaries 
Table 1 (continued)

Clagsification Act of 1949

$(10-28-49)$

Revision of clasgification system; average salary increases of $\$ 140$

Sources: Monthly Labor Review, various issues. 
Figure 1

\section{Annual Pay Ratios: GS-8 to GS-4}

\section{Ratio}

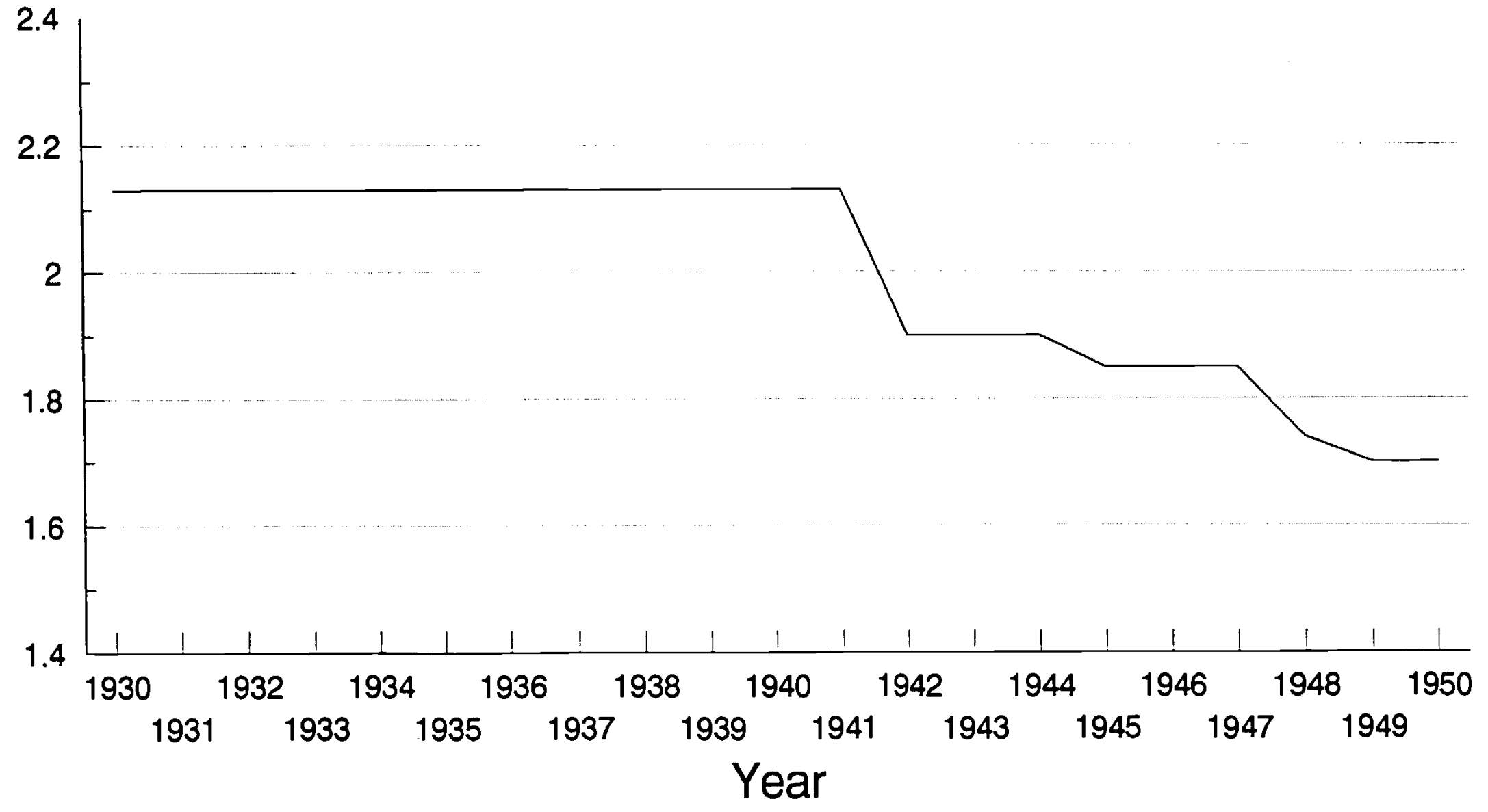

Figures are ratios of midpoints of salary scales; see text

Source: Monthly Labor Review, various issues 


\section{Figure 2}

\section{Federal-Private Wage Ratio: GS-4 Versus Full-time Manufacturing Production Workers}

Federal-Private Wage Ratio

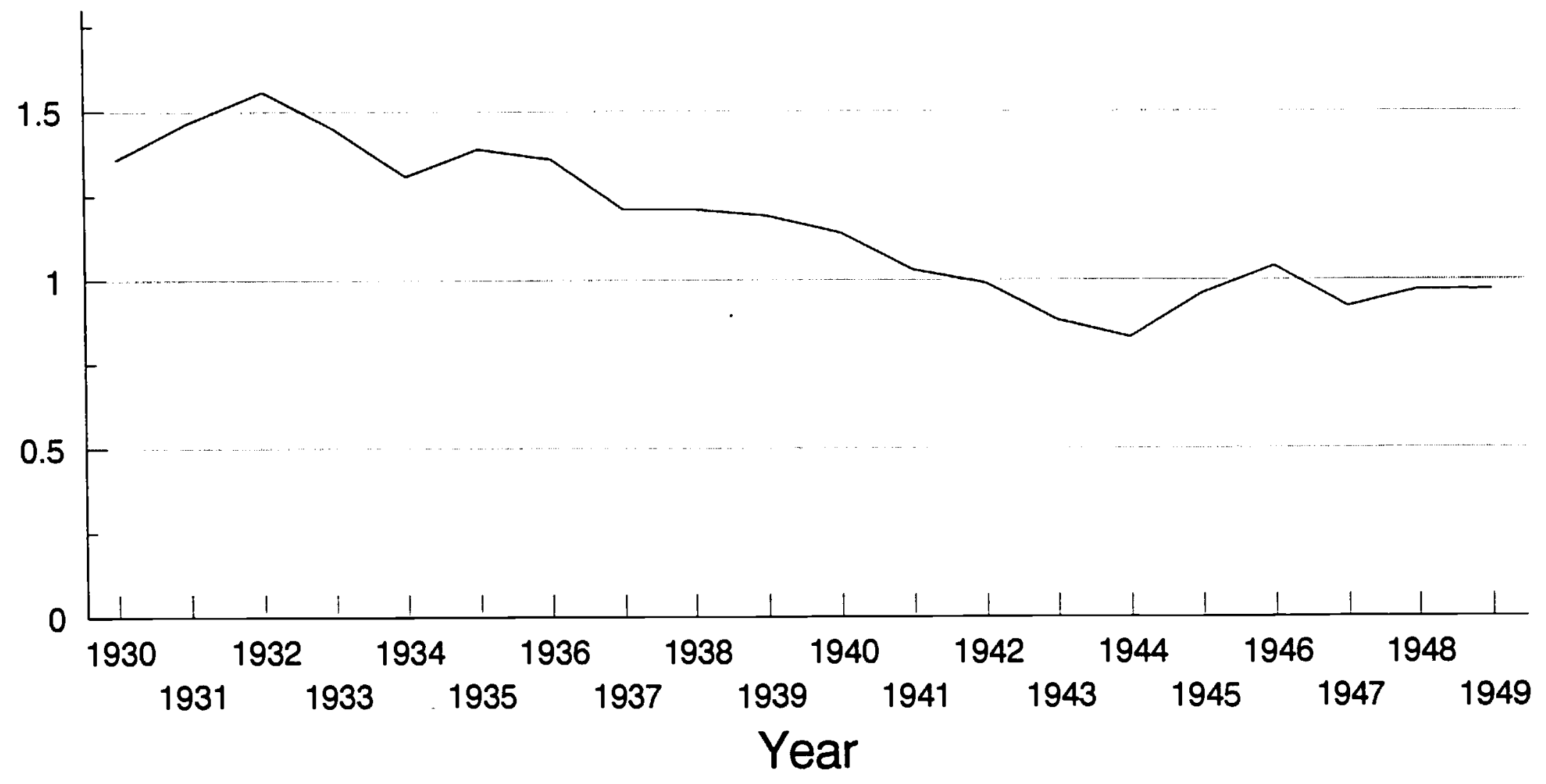

Sources: U.S. Department of Commerce (1975),

series D-802, pp. 169-70; Monthly Labor

Review (March 1951), p. 300 
Table 2

Variance Decompositions, 1940-1950: Public vs. Private

A. Variance Decompositions

$\begin{array}{lcc}\sigma^{2} \mathrm{p} & 1940 & 1950 \\ { }^{\mathrm{B}} \mathrm{p} & 0.285 & 0.256 \\ \sigma^{2} \mathrm{~g} & 0.885 & 0.878 \\ { }^{\mathrm{B}} \mathrm{g} & 0.300 & 0.186 \\ { }^{\mathrm{ln}}\left(\mu_{\mathrm{p}} / \mu_{\mathrm{g}}\right)^{2} & 0.115 & 0.122 \\ \sigma^{2} & 0.026 & 0.002\end{array}$

B. Percent Explained

$1950-1940$ Percent Explaineda
$\Delta \sigma$
$-0.041$
$B^{50} p\left[\Delta \sigma_{p}\right]$
$-0.025$
61.08
$B^{50} g\left[\Delta \sigma_{g}\right]$
$-0.014$
$34 \cdot 1$
$B^{50} \mathrm{p}^{B^{50}} \mathrm{~g}\left[\Delta \ln ()^{2}\right]$
$-0.003$
7. 3

Samples consist of males, ages 18-64 who were nonfarm wage and salary workers at the time of the census; who worked at least 40 weeks during the previous year; who earned at least one-half of the minimum wage on a full-time, weekly basis; and, in 1940, were not on work relief at the time of the census or, if unemployed during the census week, had not held a work relief job in 1939. Members of the Armed Forces are excluded in 1950 and 1960 . In 1940, figures exclude members of the Armed Forces to the extent that they reported their occupation as "soldier, sailor, etc.". weekly wage cut-offs were $\$ 5.25$ in 1940 , $\$ 8.00$ in 1950 , and $\$ 12.00$ in $1960 . p=$ private nonfarm, $g=$ government.

$\sigma^{2}={ }^{B} \sigma{ }^{2} p+{ }^{B} g{ }^{2} g+B_{p} B_{g} l n\left(\mu_{p} / \mu_{g}\right)^{2}$

Source: 1940, 1950: Government, 1/100 PUMS; Private nonfarm, $1 / 1000$ PUMS (files \#2 and \#20); 1960:1/1000 PUMS.

acomponents do not add to 100 , becauge various interaction terms are not listed from the decomposition are not listed, and because of rounding. 
Variance Decompositions: Federal vo. State-Local

A. Variance Decompositions

$\begin{array}{lll}\sigma_{f}^{2} & 1940 & 1950 \\ B_{f} & 0.247 & 0.137 \\ \sigma^{2} & 0.265 & 0.337 \\ B_{s} & 0.309 & 0.205 \\ B_{f}^{B} \ln \left(\mu_{f} / \mu_{g}\right)^{2} & 0.735 & 0.663 \\ \sigma_{g}^{2} & 0.036 & 0.017\end{array}$

B. Percent Explained

Change 1950-40 Percent Explaineda

$\begin{array}{lll}\Delta \sigma^{2} \mathrm{~g} \cdot & -0.114 & \\ \mathrm{~B}^{50} \mathrm{f} \Delta \sigma^{2} \mathrm{f} & -0.037 & 32.58 \\ \mathrm{~B}^{50} \mathrm{~g} \Delta \sigma_{\mathrm{s}}^{2} & -0.069 & 6.5 \\ \mathrm{~B}^{50} \mathrm{fB}_{\mathrm{s}}^{50} \Delta \mathrm{In}() & -0.004 & 3.5\end{array}$

Source: see Table $1 ; f=$ federal; $s=$ state-local

$\sigma_{g}^{2}=B_{f} \sigma_{f}^{2}+B_{g} \sigma_{g}^{2}+B_{f} B_{g}\left[\ln \left(\mu_{f} / \mu_{s}\right)\right]^{2}$

acomponents do not add to 100 because various interactions terms in the decomposition are not listed, and because of rounding. 


\section{Table 4}

public-private Pay Gaps and Residual wage Inequality

A. Decompogition of Public-private Pay Gap

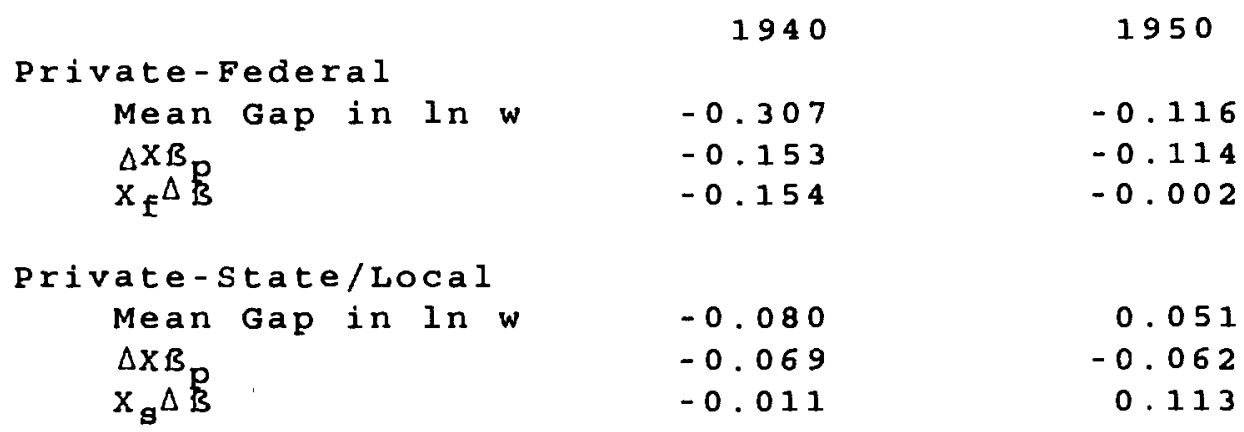

B. Change in Regidual wage Inequality, 1940-50

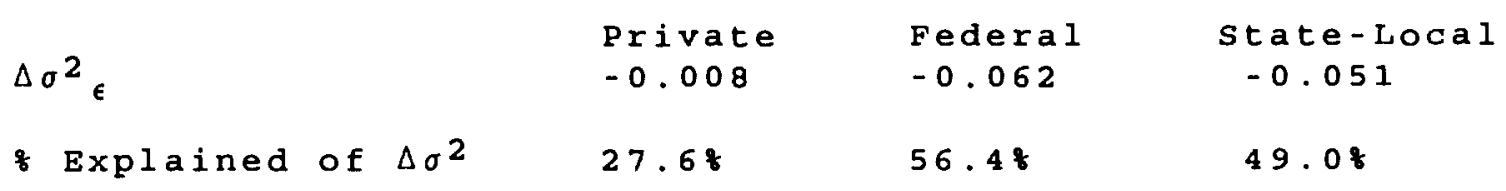

Source: see text and Appendix Table 1 
Table 5

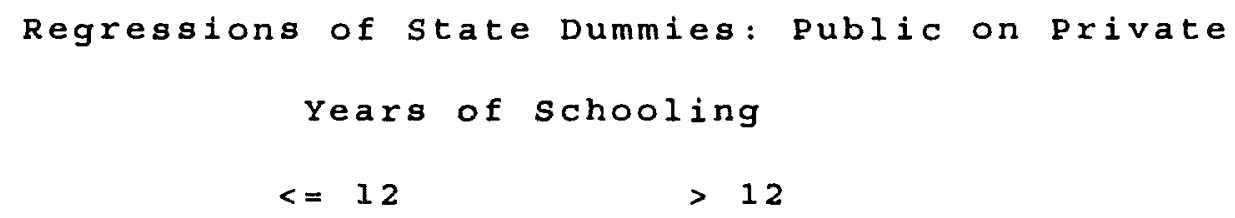

state/Local

B t-stat B $\quad$ t-stat
1940
0.867
8. 570
0.318
3. 676
1950
0.848
7.319
0.151
1. 547

Federal

$\begin{array}{lllll}1940 & 0.307 & 3.029 & 0.016 & 0.142 \\ 1950 & 0.609 & 4.629 & 0.174 & 1.423\end{array}$

$B$ : coefficient from regresion, $\delta \mathrm{g}=\alpha+\beta \delta$, where $\delta$ 's are coefficients of state dumies in log wage regressions; see text. obgervations are weighted by year-specific state labor force totals from U.S. Department of Commerce (1975).

source: see text. 


\section{Appendix Table 1}

Log Wage Regressions

A. 1940

\begin{tabular}{llll}
\multicolumn{2}{c}{ Private Federal } & \multicolumn{2}{c}{ State-Local } \\
Mean & $B$ & Mean & Mean
\end{tabular}

\begin{tabular}{|c|c|c|c|c|c|c|}
\hline Constant & & $\begin{array}{c}1.931 \\
(34.443)\end{array}$ & & $\begin{array}{c}1.399 \\
(11.595)\end{array}$ & & $\begin{array}{c}1.730 \\
(26.870)\end{array}$ \\
\hline Experience & 22.005 & $\begin{array}{c}0.048 \\
(20.613)\end{array}$ & 22.822 & $\begin{array}{c}0.064 \\
(14.972)\end{array}$ & 24.357 & $\begin{array}{c}0.052 \\
(20.434)\end{array}$ \\
\hline \multicolumn{7}{|l|}{ Experience ${ }^{2}$} \\
\hline$x \quad 10^{-2}$ & 6.472 & $\begin{array}{c}-0.062 \\
(22.008)\end{array}$ & 6.661 & $\begin{array}{c}-0.066 \\
(13.871)\end{array}$ & 7.471 & $\begin{array}{c}-0.067 \\
(21.886)\end{array}$ \\
\hline Schooling. & 9.345 & $\begin{array}{c}0.035 \\
(4.732)\end{array}$ & 11.315 & $\begin{array}{c}0.098 \\
(6.655)\end{array}$ & 10.302 & $\begin{array}{c}0.050 \\
(6.516)\end{array}$ \\
\hline \multicolumn{7}{|l|}{ Schooling ${ }^{2}$} \\
\hline$\times 10^{-2}$ & 0.300 & $(6.982)$ & $1.50=$ & $(1.138)$ & 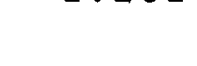 & $(7.455)$ \\
\hline \multicolumn{4}{|l|}{ Schooling $x$} & \multicolumn{2}{|c|}{ Experience } & \\
\hline$\times 10^{-2}$ & 1.846 & $\begin{array}{l}-0.051 \\
(4.047)\end{array}$ & 2.392 & $\begin{array}{c}-0.147 \\
(6.882)\end{array}$ & 2.260 & $\begin{array}{l}-0.071 \\
(5.852)\end{array}$ \\
\hline Nonwhite & 0.066 & $\begin{array}{c}-0.455 \\
(29.439)\end{array}$ & 0.056 & $\left(\begin{array}{c}-0.252 \\
(10.073)\end{array}\right.$ & 0.053 & $\left(\begin{array}{c}-0.381 \\
22.171)\end{array}\right.$ \\
\hline Foreign & 0.149 & $\begin{array}{l}-0.045 \\
(4.089)\end{array}$ & 0.063 & $\begin{array}{c}-0.026 \\
(1.111)\end{array}$ & 0.087 & $\begin{array}{c}-0.015 \\
(1.074)\end{array}$ \\
\hline Married & 0.751 & $(9.114)$ & 0.798 & $\left(\begin{array}{c}0.103 \\
5.3111)\end{array}\right.$ & 0.812 & $\begin{array}{c}0.097 \\
(7.432)\end{array}$ \\
\hline \multicolumn{7}{|l|}{ Head of } \\
\hline Household & 0.715 & $\begin{array}{c}0.110 \\
(9.106)\end{array}$ & 0.784 & $\begin{array}{c}0.1222 \\
(6.260)\end{array}$ & 0.789 & $\begin{array}{c}0.102 \\
(8.049)\end{array}$ \\
\hline South & 0.238 & $\begin{array}{c}-0.117 \\
(11.091)\end{array}$ & 0.343 & $\begin{array}{l}-0.039 \\
(2.548)\end{array}$ & 0.264 & $\begin{array}{c}-0.151 \\
(14.580)\end{array}$ \\
\hline Midwest & 0.309 & $\begin{array}{l}-0.005 \\
(0.499)\end{array}$ & 0.260 & $\begin{array}{l}-0.024 \\
(1.471)\end{array}$ & 0.271 & $\begin{array}{l}-0.082 \\
(8.361)\end{array}$ \\
\hline West & 0.110 & $\begin{array}{c}0.044 \\
(3.515)\end{array}$ & 0.142 & $\begin{array}{l}-0.060 \\
(3.190)\end{array}$ & 0.133 & $\begin{array}{l}-0.022 \\
(1.786)\end{array}$ \\
\hline Urban & 0.706 & $\begin{array}{c}0.180 \\
(21.453)\end{array}$ & 0.699 & $\begin{array}{c}0.206 \\
(16.400)\end{array}$ & 0.642 & $\begin{array}{c}0.279 \\
(34.480)\end{array}$ \\
\hline Dep.var.-mean & 3.231 & & 3.538 & & 3.347 & \\
\hline 14 & 88 & & 44 & 13 & 975 & \\
\hline$R^{2}$ & 0.366 & & 0.355 & & 0.391 & \\
\hline$\sigma_{\epsilon}$ & 0.425 & & 0.399 & & 0.434 & \\
\hline
\end{tabular}

B. 1950

\begin{tabular}{|c|c|c|c|c|c|c|}
\hline & \multicolumn{2}{|c|}{ Private } & \multicolumn{2}{|c|}{ Federal } & \multicolumn{2}{|c|}{ state-Local } \\
\hline & Mean & $B$ & Mean & B & Mean & B \\
\hline Constant & & $\begin{array}{c}2.926 \\
35.325 \text { ) }\end{array}$ & & $\begin{array}{c}3.036 \\
26.781)\end{array}$ & & $\begin{array}{c}3.168 \\
(36.075)\end{array}$ \\
\hline Experience & 23.020 & $\begin{array}{c}0.039 \\
11.584)\end{array}$ & 22.120 & $\begin{array}{c}0.036 \\
(8.339)\end{array}$ & 24.563 & $\begin{array}{c}0.030 \\
(8.881)\end{array}$ \\
\hline
\end{tabular}




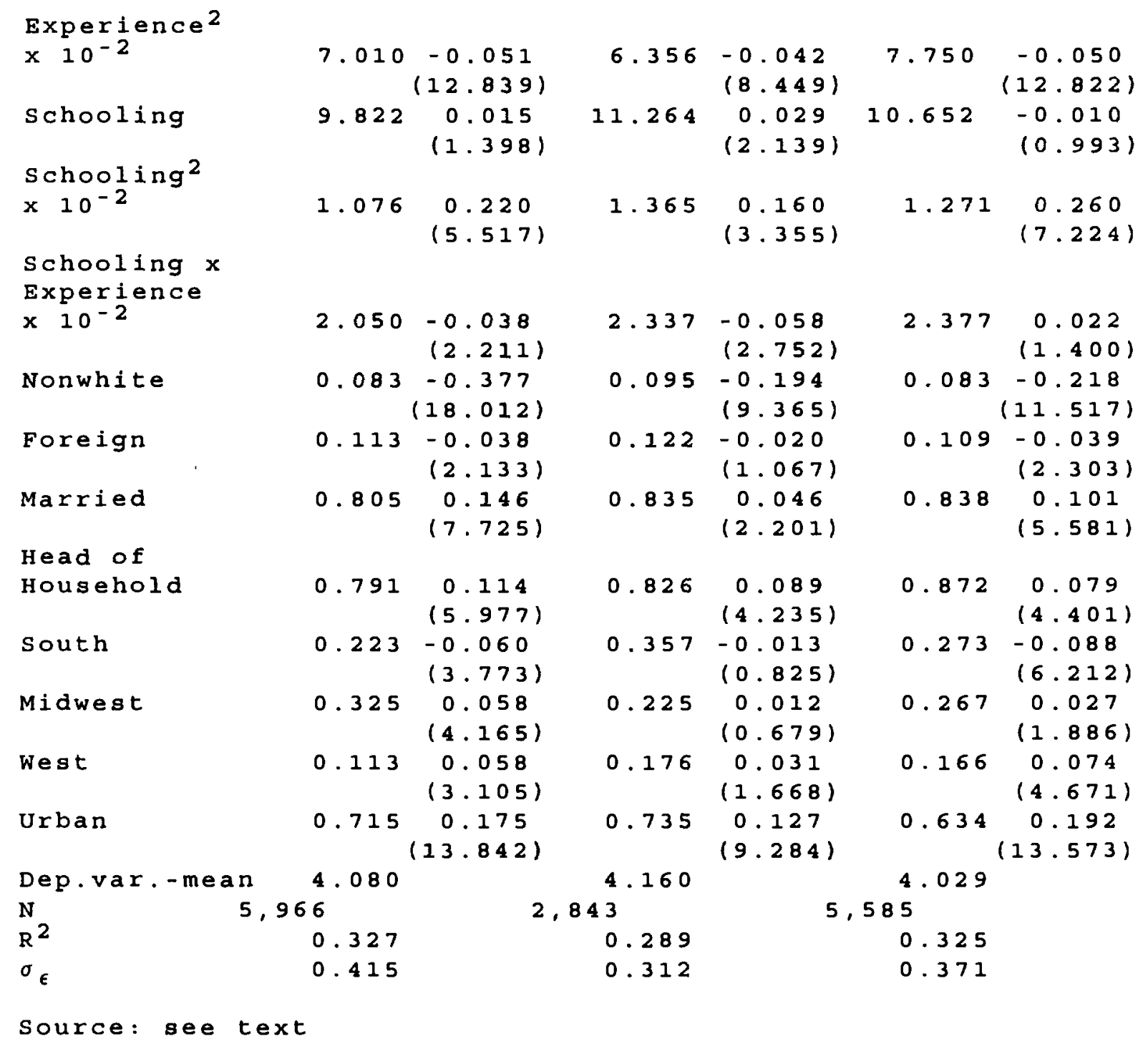

